\title{
A novel use for Levey-Jennings charts in prenatal molecular diagnosis
}

\author{
Binghuan Weng ${ }^{1^{*}} \mathbb{D}$, Ya-li Xu², Jun Ying ${ }^{2}$, Hao-kun Yang ${ }^{1}$, Lan Su', Yan-mei Yang ${ }^{1}$ and Min Chen ${ }^{1}$
}

\begin{abstract}
Background: The goal of this study was to determine whether Levey-Jennings charts, which are widely used in clinical laboratories, can be used to create standardized internal quality controls (IQCS) for prenatal molecular diagnosis.

Methods: Aneuploid amniocyte lines with trisomy 13, 21, and 18, and 47,XXY were established by transfection with SV40LTag-pcDNA3.1 (-)and combined at different ratios to generate aneuploidy chimeric quality-control cell mixtures $A$ to $H$. These quality-control cells were then used to calculate the $\bar{X}, \bar{X} \pm 1$ standard deviation (SD), $\bar{X} \pm 2$ $S D$, and $\bar{X} \pm 3$ SD values to develop standardized IQCs for methods used for the prenatal diagnosis of aneuploidies such as FISH.

Results: Methods for constructing aneuploid amniocyte lines were developed and a set of quality-control cells (A$H$ ) were prepared. The $\bar{X} \pm 1 S D, \bar{X} \pm 2 S D$, and $\bar{X} \pm 3$ SD values of these quality-control cells for trisomy 13 and 21 were 10.2 $\pm 1.7,10.2 \pm 3.4$, and 10.2 \pm 5.1 , and $90.3 \pm 2.3,90.3 \pm 4.6$, and $90.3 \pm 6.9$, respectively. Based on the values and Levey-Jennings charts, a set of standardized IQCs for prenatal diagnosis such as FISH were established.

Conclusions: This method resolves the problems of a shortage of quality-control materials and a lack of qualitycontrol charts in prenatal molecular diagnosis such as NIPT, NGS, aCGH/SNP, PCR, and FISH. Levey-Jennings chartbased IQCs for prenatal diagnosis such as FISH can be used to easily monitor whether IQC results are within acceptable limits, and then infer whether the diagnostic results for clinical samples are reliable. We expect that this standardized IQC will be useful for a wide range of molecular diagnostic laboratories.
\end{abstract}

Keywords: Aneuploidy, Molecular diagnosis, Prenatal diagnosis, Fluorescence in situ hybridization, Quality control, Standardization

\section{Background}

With the widespread development of molecular diagnostic technologies such as aneuploidy detection by fluorescence in situ hybridization (FISH) [1], noninvasive prenatal testing (NIPT) [2], and QF-PCR technique [3], standardized quality control is urgently needed to ensure that prenatal molecular diagnoses are accurate and reliable [3-5]. In general, the most important properties for

\footnotetext{
* Correspondence: 5503006@zju.edu.cn

${ }^{1}$ The Key Laboratory of Reproductive Genetics, Department of Obstetrics and Gynecology, Women's Hospital, School of Medicine, Zhejiang University, 1 Xueshi Road, Hangzhou 310006, Zhejiang, China

Full list of author information is available at the end of the article
}

quality control materials are as follows: they must behave like the real samples, and they must be available in sufficient quantity for developing internal quality control (IQC) charts to be used for monitoring quality in real time. At present, standardized IQCs are not easily available for prenatal molecular diagnosis because LeveyJennings charts have not been used in molecular biology laboratories, and there is an insufficient supply of characterized paired materials such as cells with trisomy 18 and 13 in the cell line repository [6-8].

In 1931, Shewhart proposed the use of control charts for monitoring quality in manufacturing operations [9-13]. He

(c) The Author(s). 2020 Open Access This article is licensed under a Creative Commons Attribution 4.0 International License, which permits use, sharing, adaptation, distribution and reproduction in any medium or format, as long as you give appropriate credit to the original author(s) and the source, provide a link to the Creative Commons licence, and indicate if changes were made. The images or other third party material in this article are included in the article's Creative Commons licence, unless indicated otherwise in a credit line to the material. If material is not included in the article's Creative Commons licence and your intended use is not permitted by statutory regulation or exceeds the permitted use, you will need to obtain permission directly from the copyright holder. To view a copy of this licence, visit http://creativecommons.org/licenses/by/4.0/. The Creative Commons Public Domain Dedication waiver (http://creativecommons.org/publicdomain/zero/1.0/) applies to the data made available in this article, unless otherwise stated in a credit line to the data. 
defined values greater than $3 \mathrm{~S}$ from the mean as indicating significant variation from standard quality. Over the past few decades, control charts have come to be widely used for IQC in clinical laboratories [10-14]. Levey and Jennings recommended that Shewhart's control charts be used in clinical laboratories to provide a constant means of checking the reliability of the numerous tests run each day, and to make it possible to determine at a glance whether errors of analysis are beyond the permitted statistical variation defined by the procedure created in 1950 [10]. The control limit for Levey-Jennings charts is, as it was for Shewhart, $3 S$. Henry described the use of $1 \mathrm{~S}, 2 \mathrm{~S}$, or $3 \mathrm{~S}$ control limits and 95\% confidence limits in 1959 [13], while Westgard et al. provided definitive guidelines for the interpretation of a control result that is 1 S, 2S, or 3S from the mean in 1977 [14]. However, to date there have been few reports on the application of Levey-Jennings charts to prenatal molecular genetic diagnosis.

In the current study, we developed a set of aneuploidy chimeric quality-control cells $(\mathrm{A}-\mathrm{H})$ by immortalizing aneuploid amniocytes via SV40LTtransfection to address the lack of quality-control materials for methods used in prenatal diagnosis such as NIPT, NGS, and FISH [6-8]. More importantly, we developed a Levey-Jennings chartbased IQC system for detecting fatal aneuploidies by FISH by testing these quality-control cells(A-H) and clinical samples under the same experimental conditions. This novel use of control charts for monitoring prenatal diagnostic quality resolves the problem of the lack of adequate Levey-Jennings chart-based IQCs in molecular genetic laboratories, and should be widely applicable.

\section{Methods \\ Establishment of immortalized aneuploid amniotic fluid cell lines}

The SV40LTag-pcDNA3.1(-) recombinant vector was constructed and transfected into PT67 cells (ATCC CL12284) using liposome transfection reagent to immortalize the cells [15]. The SV40LT vector produced from the immortalized PT67 cells was used to transfect primary amniocytes exhibiting trisomy 13,18 , trisomy 21 , or 47 , $\mathrm{XXY}$ to establish their immortalized amniotic fluid cell lines. After selection using G418, the immortalized amniotic fluid cell lines with passage numbers between 10 and 15 were harvested and preserved in liquid nitrogen at $196{ }^{\circ} \mathrm{C}$. These immortalized human amniotic fluid cell lines including trisomy 13,18 , trisomy 21 , or $47, \mathrm{XXY}$ were used in our study. All experiments were performed in accordance withthe Declaration of Helsinki and approved by the Insititutional Review Board of Zhejiang University School of Medicine Women's Hospital, China (approve no. 20160030, 8 April 2016).

\section{Preparation of quality-control cells (A-H)}

The trisomy 13, 18, and 21, and 47,XXY amniotic fluid cell lines were suspended at a density of $1 \times 10^{5} / \mathrm{ml}$. The trisomy 13 and 21 cell suspensions were mixed at ratios of $1: 9,3: 7,7: 3$, and 9:1 to prepare the quality-control cells $\mathrm{A}$, $\mathrm{B}, \mathrm{C}$, and D containing 10, 30, 70, and 90\% trisomy 13 and $90,70,30$, and $10 \%$ trisomy 21 cells, respectively. Similarly, the trisomy 18 and 47,XXY cell suspensions were mixed to prepare the quality-control cells $\mathrm{E}, \mathrm{F}, \mathrm{G}$, and $\mathrm{H}$ containing 10, 30, 70, and 90\% trisomy 18 and 90, 70, 30, and $10 \% 47, \mathrm{XXY}$ cells, respectively.

\section{Analysis of quality-control cells for application to FISH}

A FISH kit was purchased from Jinpujia Company (Beijing, China). In this kit, GLP13 (green) is located at $13 q 14$ and GLP21 (red) is located at 21q22. The $18 / \mathrm{X} / \mathrm{Y}$ trichrome probes localize to the centromeres of chromosomes 18, X, and Y and show sky blue, green, and red fluorescence, respectively. The cells were fixed in a mixture of methanol and acetic acid (3:1) and then stained according to the manufacturer's instructions. Technicians from the prenatal diagnosis laboratory of the Women's Hospital, School of Medicine, Zhejiang University, and the Department of Clinical Laboratory Research, Shulan Hospital, Zhejiang University, counted 100 cells with obvious target hybridization (fluorescence) signals under a fluorescence microscope for each group of clinical samples (primary amniocytes) and qualitycontrol cells. The quality-control cells (A-D) ratios for trisomy 13 or 21 hybridization signals were determined each day for 20 consecutive days to generate 20 datasets. Similarly, the quality-control cells $(\mathrm{E}-\mathrm{H})$ ratios for trisomy 18 or $47, \mathrm{XXY}$ hybridization signals were determined. The $\bar{X} \pm 1 \mathrm{SD}, \overline{\mathrm{X}} \pm 2 \mathrm{SD}$, and $\overline{\mathrm{X}} \pm 3 \mathrm{SD}$ values for the datasets for each group of quality-control cells were calculated according to the formulas $\bar{X}=\frac{\sum x}{n}$ and $\mathrm{S}=\sqrt{\frac{\sum(\mathrm{X}-\overline{\mathrm{X}})^{2}}{\mathrm{n}-1}}$ to establish Levey-Jennings chart-based IQCs for aneuploidy detection.

\section{Plotting and applying Levey-Jennings chart-based IQCs}

As an example, the Levey-Jennings charts $x$-axis was numbered $1-31$ to represent 31 days, and the $y$-axis was labeled $\bar{X}, \bar{X} \pm 1$ SD, $\bar{X} \pm 2$ SD, and $\bar{X} \pm 3$ SD. Based on the ratio of trisomy 13 to trisomy 21 cells in qualitycontrol cells (A) detected by FISH and on the LeveyJennings charts [9-13], the $\bar{X}, \bar{X} \pm 1$ SD, $\bar{X} \pm 2$ SD, and $\bar{X} \pm 3$ SD values for trisomy 13 were plotted on the Levey-Jennings chart $y$-axis to generate the LeveyJennings chart-based IQC for trisomy 13 (Fig. 2a). The Levey-Jennings chart-based IQC for trisomy 21 was created in the same way (Fig. 2b). For clinical application, the trisomy 13 and 21 ratio in quality-control cells (A) 
and in clinical samples were detected by FISH under the same experimental conditions, and the detection results for trisomy 13 in quality-control cells (A) were plotted on the Levey-Jennings chart-based IQC (Fig. 2a) to generate the experimental application of Levey-Jennings chart-based IQC for trisomy 13 detected by FISH (Fig. 2c). The experimental application of Levey-Jennings chart-based IQC for trisomy 21 detected by FISH was created in the same way (Fig. 2d). Thus, we can monitor whether the detection results for trisomy 13 and 21 in quality-control cells (A) exceeded $\overline{\mathrm{X}} \pm 2 \mathrm{SD}$ or $\overline{\mathrm{X}} \pm 3 \mathrm{SD}$ (and thus the IQC limit for the clinical reference controls), and then infer whether the test results for the clinical samples processed that day were reliable. Similarly, quality-control cells $(\mathrm{B}-\mathrm{H})$ were generated to monitor systematic or accidental laboratory errors.

\section{Interpretation of control results}

Clinical reference controls are considered to be outside of acceptable limits in the following circumstances [13, 14]: a, if one control observation is more than $3 S$ beyond either side of the mean $(1-3 \mathrm{~s})$; b, if two consecutive control observations are more than $2 \mathrm{~S}$ from the mean and both observations are on the same side of the mean $(2-2 \mathrm{~s})$; c, if four consecutive control observations exceed $1 \mathrm{~S}$ and all are on the same side of the mean (4-1 s); d, if the control values lie on opposite sides of the mean and the difference between the largest and the smallest observations exceeds $4 \mathrm{~S}(\mathrm{R}-4 \mathrm{~s})$; e, if 10 consecutive control observations fall on the same side of the mean (10X); $\mathrm{f}$, if one control value exceeds $2 \mathrm{~S}$ on either side of the mean, which is not considered outside of acceptable limits, but a "warning sign" (1-2 s).

\section{Results}

\section{Establishment of amniocyte lines}

Primary amniocytes with trisomy 13,21 , and 18 , or 47 , XXY were transfected with SV40LTag-pcDNA3.1(-)and then selected for in G418-containing medium (50-400 $\mathrm{mg} / \mathrm{L}$ ) for 7-15 days to obtain positive cell clones (Fig. 1A). When passaged in DMEM containing 10\% fetal bovine serum, these cells grew as spindle-shaped adherent cells (Fig. 1B).

\section{Components of quality-control cells $(\mathrm{A}-\mathrm{H})$}

Quality-control cells(A-H) were prepared from amniocyte lines that had been immortalized, passaged, and frozen at $-196{ }^{\circ} \mathrm{C}$ in liquid nitrogen. In total, there are eight quality control samples: A, B, C, D, E, F, G, and H (Table 1). quality-control cells (A-D) are used for quality control of tests for trisomy 13 and 21. Theoretically, these samples contain 10, 30, 70, and 90\% trisomy 13 cells and $90,70,30$, and $10 \%$ trisomy 21 cells, respectively (Table 1$)$. quality-control cells (E-H) are used for trisomy 18 and XXY, which are at the same ratios as the quality-control cells (A-D) (Table 1).

\section{Validation of quality-control cells fluorescence signals} Chromosomes 13, 21, 18, X, and $\mathrm{Y}$ in quality-control cells $(\mathrm{A}-\mathrm{H})$ were validated using a 13/21 two-color probe and an $18 / \mathrm{X} / \mathrm{Y}$ trichrome probe. These probes both yielded positive fluorescence signals (Fig. 1a-d) that were consistent with the fluorescence signals for the primary amniocytes (Fig. 1e-f).

\section{Acquisition of IQC datasets}

We prepared quality-control cells (A-D) for detection with the 13/21 probe and quality-control cells $(E-H)$ for detection with the $18 / \mathrm{X} / \mathrm{Y}$ probe. Quality-control cells A, B, C, and D contained 10, 30, 70, and 90\% trisomy 13 cells and 90, 70, 30, and 10\% trisomy 21 cells, respectively, while quality-control cells $\mathrm{E}, \mathrm{F}, \mathrm{G}$, and $\mathrm{H}$ were composed of 10,30, 70, and 90\% trisomy 18 cells and 90, 70, 30, and 10\% 47,XXY cells, respectively. Qualitycontrol cells $(\mathrm{A}-\mathrm{H})$ and the test samples were analyzed 20 times under the same conditions to obtain datasets ( $\overline{\mathrm{X}} / \mathrm{SD}$ ) for IQC (Table 1). Based on these datasets, the $\overline{\mathrm{X}} \pm 1 \mathrm{SD}, \overline{\mathrm{X}} \pm 2 \mathrm{SD}$, and $\overline{\mathrm{X}} \pm 3 \mathrm{SD}$ values were calculated for trisomy 13 and 21 and trisomy 18 and 47,XXY (Table 1) to establish Levey-Jennings chart-based IQC.

\section{Establishing the Levey-Jennings chart-based IQC}

For quality-control cell (A), the $\bar{X}, \bar{X} \pm 1 \mathrm{SD}, \overline{\mathrm{X}} \pm 2 \mathrm{SD}$, and $\bar{X} \pm 3$ SD values for trisomy 13 and 21 over 20 days of detection were used to draw Levey-Jennings charts to establish the corresponding Levey-Jennings chart-based IQC for trisomy 13 (Fig. 2a) and Levey-Jennings chart-based IQC for trisomy 21 (Fig. 2b). Similarly, Levey-Jennings chart-based IQC were established for trisomy 13, 21, and 18 , and 47,XXY in quality-control cells (B-H).

\section{Applying Levey-Jennings chart-based IQC for aneuploid detection}

Quality-control cell (A) and clinical samples were analyzed for 18 days under the same conditions (Table 2). The results from each trisomy 13 and 21 test for qualitycontrol cell (A) were plotted on Levey-Jennings chart for trisomy 13 (Fig. 2a) and for trisomy 21 (Fig. 2b) to apply the Levey-Jennings chart-based IQC for trisomy 13 (Fig. 2c) and for trisomy 21 (Fig. 2d), respectively. The results from the day 5 and day 6 tests of trisomy 13 for qualitycontrol cell (A) were 14\%, which exceeded $\overline{\mathrm{X}} \pm 2 \mathrm{SD}$ (13.6\%), indicating unreliable results from the clinical samples (Table 2 and Fig. 2c) [10-12]. Moreover, the day 9 test result for trisomy 21 in quality-control cell (A) was 98\%, exceeding $\bar{X} \pm 3$ SD (97.2\%), which also in- 

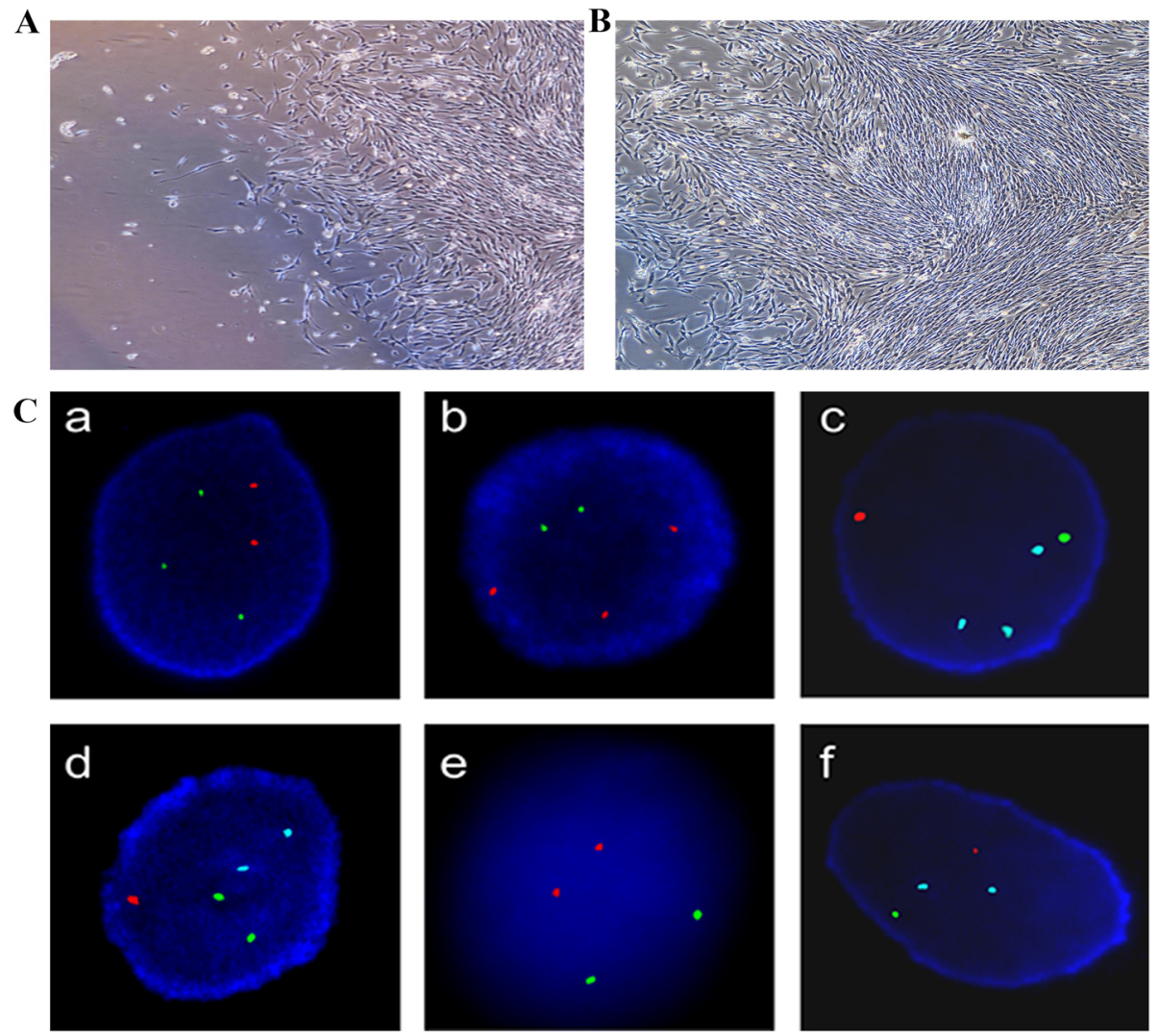

Fig. 1 Established amniocyte lines and their hybridization signals. a Primary amniocytes were transfected with SV4OLT and positive clones were obtained after selection with G418 (inverted microscope; $\times 40$ ). b Monolayer adherent spindle-shaped amniocyte lines were formed when cultured in DMEM containing 10\% fetal bovine serum (inverted microscope; $\times 40$ ). c Comparison of quality-control cells and primary amniocytes. $\mathbf{a}$ and $\mathbf{b}$ show hybridization signals of trisomy 13 and 21 in quality-control cells, respectively. $\mathbf{c}$ and $\mathbf{d}$ show the signals of trisomy 18 and XXY in quality-control cells, respectively. The number of sky blue, green, and red signals represent the number of chromosomes $18, X$, and $Y$,

respectively. e and $\mathbf{f}$ show the signals of the 13/21 two-color probe and 18/X/Y trichrome probe in primary cells, respectively

dicated unreliable results for the clinical samples (Table 2 and Fig. 2d) [10-12]. Similarly, the results from quality-control cells $(\mathrm{B}-\mathrm{H})$ corresponded with the Levey-Jennings chart-based IQC for aneuploidy detection by FISH.

\section{Discussion}

Aneuploidy is one of the most common birth defects, and is mainly detected by prenatal molecular diagnosis [1-3]. The importance of quality control in molecular diagnosis has gained considerable attention in local and international studies in recent years [3-5, 16, 17]. For example, Hardwick etal [4]. indicated that the informed use of reference standards can ensure the rigorous analysis of next generation sequencing (NGS) and is essential for its future clinical use. Stromcm et al. [5] proposed improving the accuracy of prenatal screening with DNA copy-number analysis. However, quality control materials that have properties identical to clinical samples and that are applicable to a wide range of methodologies are still not available for aneuploidy screening, because there is an insufficient supply of characterized paired samples for trisomy 18 and 13 in the cell line repository (the Coriell Institute for Medical Research) [8].

To overcome the shortage of quality control materials [6-8], we developed a set of suitable quality-control cells that comprise the common aneuploidies trisomy 13, 21, and 18, and 47, XXY based on immortalization of amniocytes by SV40LT-transfection [15] (Fig. 1A-B). The established aneuploid amniocyte lines can be amplified in vitro for more than 350 generations [15, 18], while still preserving the same differentiated phenotype and biological characteristics [19]. As shown in Fig. 1C, the amniotic cell lines selected for using G418 and passaged 10-15 times were verified using a 13/21 two-color probe and an $18 / \mathrm{X} / \mathrm{Y}$ trichrome probe, and showed clear positive signals for chromosomes $13,21,18, \mathrm{X}$, and $\mathrm{Y}$, which were consistent with the fluorescence signals of the primary cells. These results validated the genomic stability of the aneuploid amniotic cell lines transfected with SV40LT [19]. These cells lines can be used as quality control materials for aneuploidy detection by FISH and 
Table 1 Analysis of aneuploidies in quality control cells to establish internal quality controls (IQCs) for molecular genetic diagnosis ( $\bar{X} / S D / \bar{X} \pm 1 S D / 2 S D / 3 S D)$

\begin{tabular}{|c|c|c|c|c|c|c|c|c|}
\hline Group & Aneuploidy & Test (time) & Theoretical Ratio (\%) & $\overline{\mathbf{X}}(\boldsymbol{n}=20)$ & SD & $\overline{\mathbf{X}} \pm 1 S D$ & $\overline{\mathbf{X}} \pm 2 \mathrm{SD}$ & $\overline{\mathbf{X}} \pm 3 S D$ \\
\hline \multirow[t]{2}{*}{$A$} & trisomy 13 & 20 & 10 & 10.2 & 1.7 & $10.2 \pm 1.7$ & $10.2 \pm 3.4$ & $10.2 \pm 5.1$ \\
\hline & trisomy 21 & 20 & 90 & 90.3 & 2.3 & $90.3 \pm 2.3$ & $90.3 \pm 4.6$ & $90.3 \pm 6.9$ \\
\hline \multirow[t]{2}{*}{ B } & trisomy 13 & 20 & 30 & 30.4 & 2.4 & $30.4 \pm 2.4$ & $30.4 \pm 4.8$ & $30.4 \pm 7.2$ \\
\hline & trisomy 21 & 20 & 70 & 69.8 & 2.6 & $69.8 \pm 2.6$ & $69.8 \pm 5.2$ & $69.8 \pm 7.8$ \\
\hline \multirow[t]{2}{*}{ C } & trisomy 13 & 20 & 70 & 70.3 & 2.4 & $70.3 \pm 2.4$ & $70.3 \pm 4.8$ & $70.3 \pm 7.2$ \\
\hline & trisomy 21 & 20 & 30 & 30.8 & 2.1 & $30.8 \pm 2.1$ & $30.8 \pm 4.2$ & $30.8 \pm 6.3$ \\
\hline \multirow[t]{2}{*}{ D } & trisomy 13 & 20 & 90 & 90.1 & 2.4 & $90.1 \pm 2.4$ & $90.1 \pm 4.8$ & $90.1 \pm 7.2$ \\
\hline & trisomy 21 & 20 & 10 & 10.1 & 1.4 & $10.1 \pm 1.4$ & $10.1 \pm 2.8$ & $10.1 \pm 4.2$ \\
\hline \multirow[t]{2}{*}{ E } & trisomy 18 & 20 & 10 & 10.3 & 1.9 & $10.3 \pm 1.9$ & $10.3 \pm 3.8$ & $10.3 \pm 5.7$ \\
\hline & $47, X X Y$ & 20 & 90 & 90.6 & 2.4 & $90.6 \pm 2.4$ & $90.6 \pm 4.8$ & $90.6 \pm 7.2$ \\
\hline \multirow[t]{2}{*}{$\mathrm{F}$} & trisomy 18 & 20 & 30 & 30.0 & 2.6 & $30.0 \pm 2.6$ & $30.0 \pm 5.2$ & $30.0 \pm 7.8$ \\
\hline & $47, X X Y$ & 20 & 70 & 69.8 & 2.5 & $69.8 \pm 2.5$ & $69.8 \pm 5.0$ & $69.8 \pm 7.5$ \\
\hline \multirow[t]{2}{*}{ G } & trisomy 18 & 20 & 70 & 70.1 & 2.4 & $70.1 \pm 2.4$ & $70.1 \pm 4.8$ & $70.1 \pm 7.2$ \\
\hline & $47, X X Y$ & 20 & 30 & 29.9 & 2.6 & $29.9 \pm 2.6$ & $29.9 \pm 5.2$ & $29.9 \pm 7.8$ \\
\hline \multirow[t]{2}{*}{$\mathrm{H}$} & trisomy 18 & 20 & 90 & 90.6 & 2.6 & $90.6 \pm 2.6$ & $90.6 \pm 5.2$ & $90.6 \pm 7.8$ \\
\hline & $47, X X Y$ & 20 & 10 & 10.1 & 1.3 & $10.1 \pm 1.3$ & $10.1 \pm 2.6$ & $10.1 \pm 3.9$ \\
\hline
\end{tabular}

to generate highly biomimetic control materials for NIPT and single-gene disorders based on enzymatic digestion for use in test validation, IQC, and proficiency testing in clinical or laboratory settings [8].

Our main purpose was to create a novel use for LeveyJennings charts in molecular biology laboratories by developing characterized paired quality-control cells. Levey-Jennings charts, which were initially used by Westgard to monitor the quality of manufacturing operations, were recommended for use in clinical laboratories by Levey and Jennings to judge whether the observed control measurements (or observations) represent reliable or unreliable performance of the analytical method, which in turn may suggest certain sources of error, and so aid in problem solving $[9,10]$. Henry, and especially Westgard, ultimately formulated a system of rules to enable clinical laboratory scientists to decide whether the tests they were doing were within acceptable limits and therefore reportable, or outside of acceptable limits [11, 12]. Levey-Jennings charts have been used in laboratories for over 50 years to systematically monitor for errors [9-13]. However, they have not been used in prenatal molecular diagnostic laboratories to establish standardized Levey-Jennings chart-based IQCs for monitoring the quality of molecular diagnostic methods such as FISH in real-time.

We used FISH as a representative method to study the feasibility of establishing Levey-Jennings chart-based IQCs for monitoring molecular diagnostic quality, because FISH is widely used to detect aneuploidies after amniocentesis and to perform chromosome analysis of leukemic blood samples and other tissues [20-24]. In general, each clinical sample only includes one karyotype. However, chimeric samples can contain various karyotypes, including $\mathrm{XX} / \mathrm{XY}$ sex mosaicism and autosomal trisomy or sex mosaicism and trisomy 13 [25]. Compared with non-chimeric karyotypes, chimeric karyotypes are more common and are more easily misdiagnosed in prenatal diagnosis by FISH, particularly in individuals with a low proportion of multiple karyotypes [24-26]. Thus, considering that the accuracy of aneuploidy detection by FISH can be improved by increasing cell counts [20-22, 27], and that quality-control cells containing different proportions of karyotypes can more accurately assess detection quality [26], we used 60 and $20 \%$ as the thresholds for aneuploidy detection [28, 29]. We prepared high-, medium-, and low-value qualitycontrol cells (A-H) with aneuploidy ratios of 10, 30, 70, and $90 \%$, respectively, to provide a relatively consistent ratio of chimeras to the common clinical samples with various karyotypes as the basis to establish an ideal IQC for prenatal molecular diagnosis by FISH [20-24]. Although the quality-control cells transfected with SV40LT are not identical to primary amniocytes and Phaseolus vulgaris-leucoagglutinin (PHA)-stimulated lymphocytes used for FISH quality control approaches in 26 laboratories [30], they have several advantages as IQCs. First, the quality-control cells were made from homologous primary amniotic fluid cells that are used for prenatal testing for aneuploidies. Second, the quality-control cell fluorescence signals were consistent with those of noncultured primary amniocytes detected by FISH (Fig. 1C). 


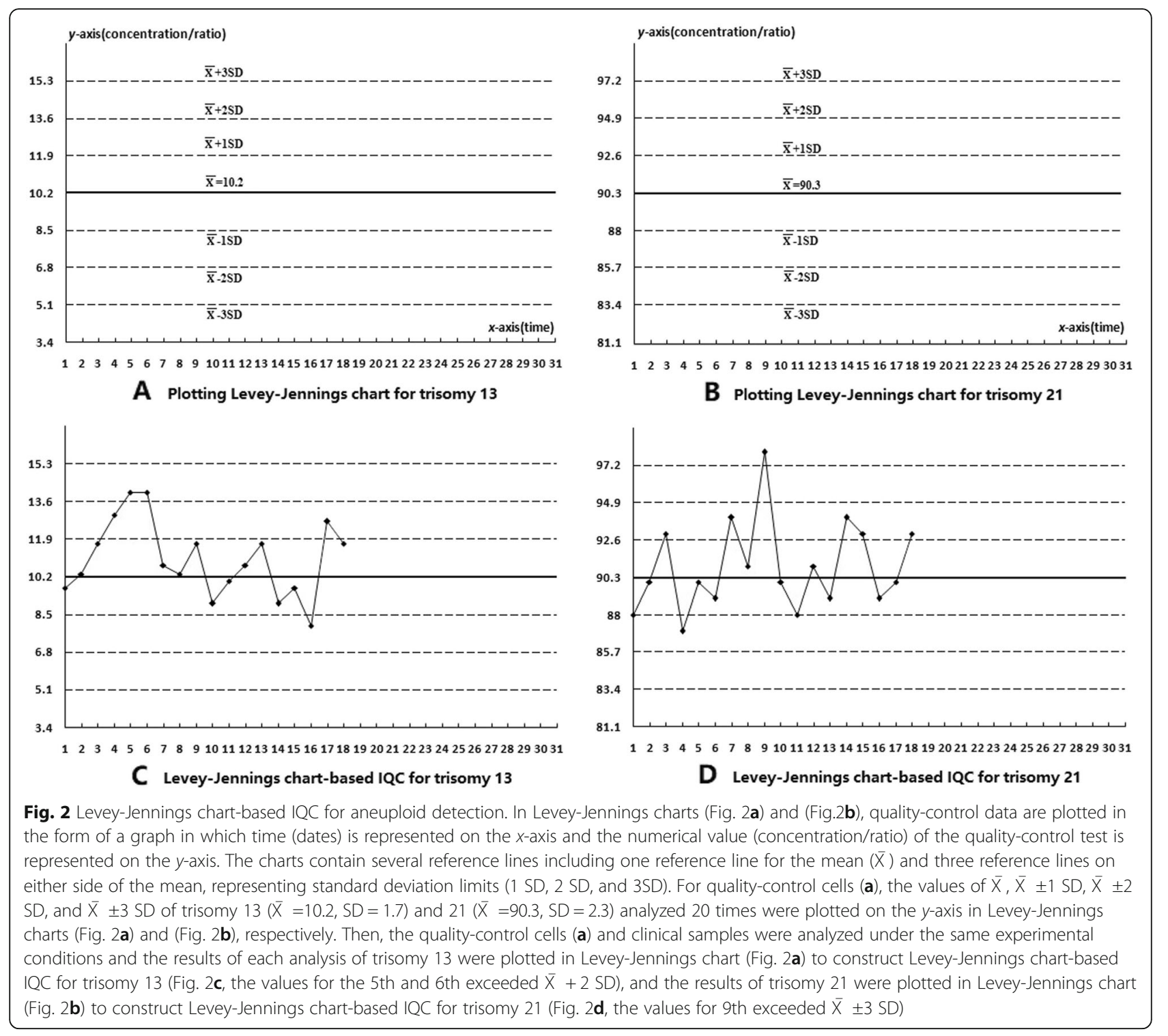

Third, the quality-control cells contain four karyotypes in different proportions with properties similar to chimeric clinical samples, which makes them applicable to evaluating the sensitivity of FISH and convenient for use in quality control. Fourth, quality-control cells prepared from immortalized amniocytes can be effectively produced on a large scale to generate highly biomimetic quality control materials for NIPT [8]. In our study, the results from the detection of trisomy 13 and 21 for quality-control cell (A) were transformed into data that can be used to plot Levey-Jennings charts to establish Levey-Jennings chart-based IQC for aneuploid detection and then monitor whether results are reliable or not [9-13].

Table 2 Aneuploidies in quality control cells (A and F) determined by applying molecular genetic diagnosis IQCs based on LeveyJennings charts

\begin{tabular}{|c|c|c|c|c|c|c|c|c|c|c|c|c|c|c|c|c|c|c|c|}
\hline \multirow[t]{2}{*}{ Aneuploidy } & \multirow[t]{2}{*}{ Probe } & \multicolumn{18}{|c|}{ Quality control cells (A and F)-based IQC results over 18 consecutive days } \\
\hline & & 1 & 2 & 3 & 4 & 5 & 6 & 7 & 8 & 9 & 10 & 11 & 12 & 13 & 14 & 15 & 16 & 17 & 18 \\
\hline Trisomy 13 & GLP13/21 & 10 & 10 & 12 & 13 & 14 & 14 & 11 & 10 & 12 & 9 & 10 & 11 & 12 & 9 & 10 & 8 & 13 & 12 \\
\hline Trisomy 21 & GLP13/21 & 88 & 90 & 93 & 87 & 90 & 89 & 94 & 91 & 98 & 90 & 88 & 91 & 89 & 94 & 93 & 89 & 90 & 93 \\
\hline Trisomy 18 & $18 / X / Y$ trichrome & 31 & 34 & 28 & 27 & 30 & 27 & 38 & 29 & 30 & 34 & 22 & 29 & 33 & 28 & 27 & 33 & 28 & 32 \\
\hline $47, X X Y$ & 18/X/Y trichrome & 68 & 69 & 70 & 69 & 61 & 68 & 67 & 70 & 68 & 71 & 69 & 73 & 68 & 70 & 68 & 76 & 69 & 73 \\
\hline
\end{tabular}


As shown in Fig. 2, the Levey-Jennings chart-based IQC for aneuploid detection contains quality control data plotted in the form of a graph in which time (date) is represented on the $x$-axis and the numerical value of the quality control test is represented on the $y$-axis. Moreover, it contains several reference lines, including one for the mean and three on either side of the mean representing standard deviation limits $(1 \mathrm{SD}, 2 \mathrm{SD}$, and 3 SD) [9-12]. As shown in Fig. 2c, the Levey-Jennings chart-based IQC demonstrated that the values for six trisomy 13 tests increased gradually over time, and the values for the tests performed on days 5 and 6 exceeded $\overline{\mathrm{X}} \pm 2$ SD (outside of acceptable limits) [10-12], which is likely to represent a systematic error caused by control materials, instrument calibration, reagent blanks, or similar factors that affected all measurements in the same way. As shown in Fig. 2d, the day 9 test for trisomy 21 exceeded $\overline{\mathrm{X}} \pm 3 \mathrm{SD}$ on the Levey-Jennings chartbased IQC (outside of acceptable limits) [9-12], which was likely to be a random error introduced by a technician when the sample was being processed. This realtime quality monitoring showed that the test results for the clinical samples on the day that the IQC was performed (outside of acceptable limits) were unreliable. The reasons for this should be identified, and the samples re-tested [10-14].

\section{Conclusion}

The Levey-Jennings chart-based IQC for aneuploid detection can be used to monitor in real-time whether the quality control results are outside of acceptable limits and then determine whether the test results for the clinical samples are reliable, which should be widely applicable for IQC in prenatal molecular diagnostical laboratory.

\section{Abbreviations}

IQC: Internal quality control; FISH: Fluorescence in situ hybridization; SV40LT: Simian virus 40 large T; G418: Geneticin 418

\section{Acknowledgements}

We thank Emily Crow, PhD for editing the English text of a draft of this manuscript. We sincerely thank all patients, clinicians, and biologists involved in this project.

\section{Authors' contributions}

All authors participated in the design, interpretation of the studies and analysis of the data and review of the manuscript; BHW conducted the experiments, wrote the manuscript, and supplied all laboratory reagents; $Y L X$, $J Y, H K Y, L S, Y M Y$, and CM conducted the experiments, collected and managed samples. All authors have read and approved the manuscript, and ensure that this is the case.

\section{Funding}

This study was financially supported by the National Natural Science Foundation of China (No. 81671467), and the Medicine and Health Science and Technology Plan Projects in Zhejiang Province under grant number 201494417. The funding bodies played no role in the design of the study and collection, analysis, and interpretation of data and in writing the manuscript.

\section{Availability of data and materials}

All data generated or analyzed during this study are included in this published article.

\section{Ethics approval and consent to participate}

The study was performed in accordance with the Declaration of Helsinki and approved by the Insititutional Review Board of Zhejiang University School of Medicine Women's Hospital, China (approve no. 20160030, 8 April 2016). All experiments were performed in accordance with relevant guidelines and regulations. All participants signed a document of informed consent before the participation of the study.

\section{Consent for publication}

Not Applicable.

\section{Competing interests}

The authors declare that they have no competing interests.

\section{Author details}

The Key Laboratory of Reproductive Genetics, Department of Obstetrics and Gynecology, Women's Hospital, School of Medicine, Zhejiang University, 1 Xueshi Road, Hangzhou 310006, Zhejiang, China. ${ }^{2}$ Department of Clinical Laboratory Research, Shulan Hospital, Zhejiang University, 848 Dongxin Road, Hangzhou 310006, Zhejiang, China.

Received: 25 May 2020 Accepted: 23 July 2020

Published online: 31 July 2020

\section{References}

1. Ried T, Landes G, Dackowski W, Klinger K, Ward DC. Multicolor fluorescence in situ hybridization for the simultaneous detection of probe sets for chromosomes 13,18,21,X and $Y$ in uncultured amniotic fluid cells. Hum Mol Genet. 1992;1:307-13.

2. Bianchi DW, Parker RL, Wentworth J, Madankumar R, Saffer C, Das AF, Craig JA, Chudova DI, Devers PL, Jones KW, Oliver K, Rava RP, Sehnert AJ, CARE Study Group. DNA sequencing versus standard prenatal aneuploidy screening. N Engl J Med. 2014;370:799-808.

3. Masoudzadeh N, Teimourian S. Comparison of quantitative fluorescent polymerase chain reaction and karyotype analysis for prenatal screening of chromosomal aneuploidies in 270 amniotic fluid samples. J Perinat Med. 2019:47:631-6.

4. Hardwick SA, Deveson IW, Mercer TR. Reference standards for nextgeneration sequencing. Nat Rev Genet. 2017:18:473-84.

5. Strom CM, Maxwell MD, Owen R. Improving the accuracy of prenatal screening with DNA copy-number analysis. N Engl J Med. 2017;376:188-9.

6. Blackburn J, Wong T, Madala BS, Barker C, Hardwick SA, Reis ALM, Deveson IW, Mercer TR. Use of synthetic DNA spike-in controls (sequins) for human genome sequencing. Nat Protoc. 2019;14:2119-51.

7. Hardwick SA, Chen WY, Wong T, Kanakamedala BS, Deveson IW, Ongley SE, Santini NS, Marcellin E, Smith MA, Nielsen LK, Lovelock CE, Neilan BA, Mercer TR. Synthetic microbe communities provide internal reference standards for metagenome sequencing and analysis. Nat Commun. 2018;9: 3096.

8. Zhang R, Ding J, Gao P, Li ZY, Tan P, Li JM. Generation of highly biomimetic quality control materials for noninvasive prenatal testing based on enzymatic digestion of matched mother-child cell lines. Clin Chem. 2019; 65:6761-70

9. Levey S, Jennings ER. The use of control charts in the clinical laboratory. Arch Pathol Lab Med. 1992;116:791-8.

10. Levey S, Jennings ER. The use of control charts in the clinical laboratory. Am J Clin Path. 1950;20:1059-66.

11. Henry RT. Use of the control chart in clinical chemistry. Clin Chem. 1959;5: 309-19.

12. Westgard JO, Groth T, Aronsson T, Falk H, de Verdier CH. Performance characteristics of rules for internal quality control: probabilities for false rejection and error detection. Clin Chem. 1977;23:1857-67.

13. Carroll TA, Pinnick HA, Carroll WE. Probability and the Westgard rules. Ann Clin Lab Sci. 2003;33:113-4.

14. Coskun A. Modified Levey-Jennings charts for calculated laboratory tests. Clin Chem Lab Med. 2006:44:387-90. 
15. Kirchhoff C, Araki Y, Huhtaniemi I, Matusik RJ, Osterhoff C, Poutanen M, Samalecos A, Sipilä P, Suzuki K, Orgebin-Crist MC. Immortalization by large T-antigen of the adult epididymal duct epithelium. Mol Cell Endocrinol. 2004:216:83-94.

16. Palomaki GE, Bupp C, Gregg AR, Norton ME, Oglesbee D, Best RG, ACMG Biochemical Genetics Subcommittee of the Laboratory Quality Assurance Committee. Laboratory screening and diagnosis of open neural tube defects, 2019 revision: a technical standard of the American College of Medical Genetics and Genomics (ACMG). Genet Med. 2020;22:462-74.

17. De Biase I, Tortorelli S, Kratz L, Steinberg S, Cusmano-Ozog K, Braverman N, ACMG Laboratory Quality Assurance Committee. Laboratory diagnosis of disorders of peroxisomal biogenesis and function: a technical standard of the American College of Medical Genetics and Genomics (ACMG). Genet Med. 2020;22:686-97.

18. Campisi J. Replicative senescence: an old lives' tale? Cell. 1996:84:497-500.

19. Kim CW, Go RE, Lee GA, Kim CD, Chun YJ, Choi KC. Immortalization of human corneal epithelial cells using simian virus 40 large T antigen and cell characterization. J Pharmacol Toxicol Methods. 2016;78:52-7.

20. Weise A, Liehr T. Rapid prenatal aneuploidy screening by fluorescence in situ hybridization (FISH). Methods Mol Biol. 1885;2019:129-37.

21. Wu TH, Zhu YH, Hong L, Lin Q, Chen CM, Yang J, Ye L, Huang W, Zeng Y. Evaluation of two aneuploidy screening tests for chorionic villus samples: Multiplex ligation-dependent probe amplification and fluorescence in situ hybridization. Mol Cell Probes. 2019:46:101422.

22. Pietrzyk A, Ryłów M, Bryśkiewicz M, Studniak E, Piotrowski K, Zajączek S, Gronwald J. Evaluation of microfluidics-FISH method in prenatal diagnosis. Ginekol Pol. 2017;88:670-3.

23. Russo R, Sessa AM, Fumo R, Gaeta S. Chromosomal anomalies in early spontaneous abortions: interphase FISH analysis on 855 FFPE first trimester abortions. Prenat Diagn. 2016;36:186-91.

24. Faggioli F, Vijg J, Montagna C. Four-color FISH for the detection of low-level aneuploidy in interphase cells. Methods Mol Biol. 2014;1136:291-305.

25. Sifakis S, Anagnostopoulou K, Plastira K, Vrachnis N, Konstantinidou A, Sklavounou E. Rare case of XX/XY mosaicism and trisomy 13 in early prenatal diagnosis. Birth Defects Res A Clin Mol Teratol. 2012;94:245-8.

26. Mao YC, Su L, Li HG, Yang Y, Weng BH. Desirable quality-control materials for the establishment of qualified external quality assessment on prenatal diagnosis of chromosomal aneuploidies. Clin Chim Acta. 2018;487:80-3.

27. Aypar U, Thorland EC, Hoppman N. Prenatal diagnosis of chromosome abnormalities: past, present, and future. Chin Chem. 2013;59:1432-4.

28. D'Alton ME, Malone FD, Chelmow D, Ward BE, Bianchi DW. Defining the role of fluorescence in situ hybridization on uncultured amniocytes for prenatal diagnosis of aneuploidies. Am J Obstet Gynecol. 1997;176:769-74.

29. Tepperberg J, Pettenati MJ, Rao PN, Lese CM, Rita D, Wyandt H, Gersen S, White B, Schoonmaker MM. Prenatal diagnosis using interphase fluorescence in situ hybridization (FISH): 2-year multi-center retrospective study and review of the literature. Prenat Diagn. 2001;21:293-301.

30. Dewald G, Stallard R, Al Saadi A, Arnold S, Bader PI, Blough R, Chen K, Elejalde BR, Harris CJ, Higgins RR, Hoeltge GA, Hsu WT, Kubic V, McCorquodale DJ, Micale MA, Moore JW, Phillips RM, Scheib-Wixted S, Schwartz S, Siembieda S, Strole K, VanTuinen P, Vance GH, Wiktor A, Zinsmeister A. A multicenter investigation with interphase fluorescence in situ hybridization using X-and Y-chromosome probes. Am J Med Genet. 1998; 76:318-26.

\section{Publisher's Note}

Springer Nature remains neutral with regard to jurisdictional claims in published maps and institutional affiliations.

Ready to submit your research? Choose BMC and benefit from:

- fast, convenient online submission

- thorough peer review by experienced researchers in your field

- rapid publication on acceptance

- support for research data, including large and complex data types

- gold Open Access which fosters wider collaboration and increased citations

- maximum visibility for your research: over $100 \mathrm{M}$ website views per year

At BMC, research is always in progress.

Learn more biomedcentral.com/submissions 